\title{
Tax Incentives For Indonesian Philanthropy: The Balance of Effectiveness of Pull Factor and The Role of The State
}

\author{
Haula Rosdiana ${ }^{1}$, Murwendah ${ }^{2}$, Inayati ${ }^{3}$
}

\begin{abstract}
This study aims to evaluate the tax policy on philanthropy in Indonesia. The data are analyzed using mixed approach. The findings of this study indicate that the lack of dynamics in current tax policy is not in harmony with the rapid development of increasingly varied philanthropic activities. Therefore, the donors and recipients face uncertainty related to taxation on philanthropy including tax treatment and tax incentives that can be obtained from the government. Applicable tax policies have not been able to provide incentives for various types of taxes. In other words, the policy of tax incentives on philanthropy activities has not been a pullfactor fo rthe community to be more actively involved in philanthropy activities. Regulatory improvement is necessary, including accommodation of incentives for all types of taxes onphilanthropy in Indonesia.
\end{abstract}

Keywords: Policy Evaluation, Philanthropy, Tax Policy, Tax Incentives, Indonesia

${ }^{1,2,3}$ Department of Fiscal Administrative Science, Faculty of Administrative Science, Universitas Indonesia E-Mail: 'h.rosdiana@ui.ac.id, ${ }^{2}$ murwendah09@ui.ac.id, ${ }^{3}$ inayati.si@ui.ac.id 
Abstrak. Penelitian ini bertujuan untuk mengevaluasi kebijakan pajak filantropi di Indonesia. Data dianalisis dengan menggunakan pendekatan campuran. Temuan penelitian ini menunjukkan bahwa kurangnya dinamika dalam kebijakan perpajakan saat ini tidak selaras dengan perkembangan pesat kegiatan filantropi yang semakin bervariasi. Oleh karena itu, para donor dan penerima menghadapi ketidakpastian terkait perpajakan filantropi termasuk perlakuan pajak dan insentif pajak yang dapat diperoleh dari pemerintah. Kebijakan pajak yang berlaku belum dapat memberikan insentif untuk berbagai jenis pajak. Dengan kata lain, kebijakan insentif pajak pada kegiatan filantropi belum menjadi faktor penarik bagi masyarakat untuk lebih aktif terlibat dalam kegiatan filantropi. Selanjutnya, masalah yang terkait dengan administrasi pajak masih ditemukan dalam implementasinya. Perbaikan regulasi diperlukan, termasuk akomodasi insentif untuk semua jenis pajak untuk filantropi di Indonesia.

Kata kunci: Evaluasi Kebijakan, Filantropi, Kebijakan Pajak, Insentif Pajak, Indonesia 


\section{Introduction}

Regarding the issue of resources faced by the national government, there is an interest in understanding the role of philanthropy in addressing the urgent global societal needs and strengthening civil society for the past two decades (Garciaa, Osilia, and Koua, 2017, p.1). In Indonesia, the issue of philanthropy reemerges since last years, particularly related to the issue of taxation. Apart from discussing philanthropy in the 2nd "Philanthropy Learning Forum" in December 2015, philanthropic activists also hold major activities, namely Philanthropy Festival in 2016. These forums explore the issues arising in the implementation of tax policies on philanthropy. Therefore, it can be said that these big events are the trigger for more in-depth evaluation related to tax policy on philanthropy and its implementation since tax incentives fought ${ }^{1}$ by the Initiative for Strengthening Indonesian Philanthropy ${ }^{2}$ seem to cease after Law No. 36 of 2008 on Income Tax (hereinafter called Income Tax Law 2008) is ratified on September 23, 2008 and declared effective on January 1, 2009. However, the tax policy on philanthropy is still partial. The regulation for the implementation of Income Tax Law 2008 related to philanthropy is not immediately published, leading to a one-year vacancy resulting in inability of the philanthropic activists to exploit the incentives of income tax for philanthropy. Therefore, the implementation of tax incentives for philanthropy over the last 9 years requires a comprehensive, holistic and impartial evaluation.

Philanthropy is not merely a fund-raising activity. Philanthropy means an activity that has a strong relation with solidarity and social activity. For example, when one of the provinces in Indonesia, namely Aceh, was hit by tsunami in 2004, the Tsunami Evaluation Committee consisting of United Nations (UN) and Nongovernmental Organizations (NGOs) agencies describes the commitment to aid Aceh as the most generous and the fastest form of humanitarian response in history (Carla: 2014). Therefore, philanthropy is significant to consider in building public participation in governance or at least in helping the government to implement the allocation function related to social welfare.

Indonesian people easily tend to donate money for charity activities and volunteer in organizational voluntary activities. World Giving Index 2016 states that Indonesia is ranked second in the rating of giving and charity under Myanmar (1), following by developed countries such as New Zealand (4), USA (5), Australia (6),

\footnotetext{
${ }^{1}$ The process is carried out during 2005 to 2007.

${ }^{2}$ Haula Rosdiana is one of the members of the Initiative for Strengthening Indonesian Philanthropy fighting for tax incentives on philanthropy in Indonesia.
} 
and Canada (7) (CAF, 2017). Generally, people use official institutions recognized by the government, such as Indonesia National Zakat Agency (BAZNAS), PKPU Human Initiative, Indonesia Zakat Initiative (IZI), and Dompet Dhuafa, to distribute religious donations (particularly in Islamic context). In addition, onlinebased charity allowing people to raise funds for humanitarian and social activities, such as through www.kitabisa.com, facilitates people to channel their donations formally. For certain companies and organizations, the policy of Corporate Social Responsibility (CSR) is established. CSR is the obligation regulated in Article 74 of Law No. 40 of 2007 on Limited Liability Company (PT). In addition to PT, domestic and foreign investors, Permanent Establishment (BUT) conducting business on Oil and Gas, and SOEs are required to apply CSR (Law, 2013). Government policies in Indonesia have encouraged business organizations in certain sectors to undertake philanthropy activities, so there is an opportunity for increased philanthropy activities in the future.

Unfortunately, the condition is contrary to the findings of The Index of Global Philanthropy and Remittances of 2015 and 2016. Although most people in Indonesia agree that philanthropy is a positive and valuable activity, it has not been reflected in government policies, such as the regulatory issues of tax and licensing. The findings indicate the lack of incentive tax for nonprofit organizations. Moreover, the requirements of reporting for non-profit organizations receiving foreign funds are time-consuming, and the requirements for duration of residency and minimum asset give difficulty to foreign entities (Hudson Institute, 2016).

In Indonesia, tax incentives for philanthropy are still limited in terms of the type of tax, tax incentives provided and the sectors targeted by philanthropy. In Indonesia, tax incentives for philanthropy are categorized into two, namely tax exemption and tax deduction. The tax exemption applies to donations or income derived from non-profit organizations or the property tax from a transaction of assets transferred for certain sector, while tax deduction applies to the donor or philanthropists, both individuals and companies, as regulated in the Income Tax Law 2008. In practice, philanthropy still leaves tax-related issues that must be shouldered by donors, recipients, and donation collectors. In addition, there is a lack of socialization followed by the absence of comprehensive guidance in implementing the policy, resulting in multi-interpretation of some tax provisions and loopholes in the implementation.

In addition to limited tax incentives, sectoral scope receiving tax incentives is also limited. As regulated in the Income Tax Law 2008 and its derivative regulation, 
the incentives of income tax are limited on donations provided for the sectors of education, development, research, religion and social infrastructures (Philantrophy, 2016)). In addition, the types of tax incentives provided tend to be limited to income tax. The government has not looked at other types of potential taxes to be granted tax incentives, such as Value Added Tax (VAT) and Duty on the Acquisition of Rights to Land and Building (BPHTB) as local taxes, also Tax on Motor Vehicle and Duty on the transfer of Motor Vehicle rights.

There are many other crucial sectors to obtain fund through philanthropy. Several studies suggest that the regulatory and fiscal environment formed by the government's policies and decisions is a determinant factor in encouraging philanthropy. Wang, Graddy and Morgan (2011 in Garciaa, Osilia, and Koua, 2017 , p.5) find that the complexity of the tax system in Japan, China, and South Korea distorts individual donors to contribute to philanthropy. Even in several countries in Asia, the lack of regulations governing all types of Civil Society Organizations (CSOs) causes CSOs are difficult to develop (Chao and Onyx 2015 in Garciaa, Osilia, and Koua, 2017, p.5). It is also stated by Anand and Hayling (2014 in Garciaa, Osilia, and Koua, 2017, p.5) that the policy of tax collection in Southeast Asia tends to be poor-formulated and difficult to implement. According to Colombo (2001 in Garciaa, Osilia, and Koua, 2017, p.5), private philanthropic giving can be influenced using fiscal policies. It will increase the total donations to non-profit organizations and explain crossnational differences (Koele, 2007). Many countries grant tax exemption to nonprofit organizations and philanthropic giving from tax deduction (Wiepking and Handy, 2015, p.17). In contrast to previous studies, this study examines the comprehensive tax policy on philanthropy, not only including income tax but also VAT and Property Tax.

This study aims to evaluate tax policy on philanthropy, a part of the nonprofit sector in Indonesia. Philanthropy can be interpreted as a voluntary and private initiative to serve public interest. A philanthropic organization is bound by public interests rather than self-interest. As long as the public interests are served, philanthropy can be granted in the form of a gift by a wealthy individual or sponsorship by a for-profit organization (Koele, 2007). Due to the wide range of philanthropic activities, the study is limited and focused on the transactions for supply of goods and/or services from a donor to a recipient, particularly in the context of the collection of Income Tax, VAT, and BPHTB. 


\section{Theoretical Framework}

The understanding of tax or other levies can partially distort the strategic role of a sector or an industry. In this case, the concept of supply-side tax policy emphasizes that the tax may influence economic behavior and the effect of tax substitution is essential to ensure the efficient allocation of tax revenue (Rosdiana \& Irianto, 2013, p. 87). The basic philosophy of this concept includes 1) the regulation of tax provisions or treatment are still missing or unclear, (2) deregulation of tax regulations resulted in high cost of taxation, and (3) deregulation of tax regulations disrupts cash flow (Rosdiana, 2008). This concept is also identical with the policy of tax incentives reducing the tax burden. Tax incentives are defined as all forms of incentives that reduce the tax burden in order to encourage companies to invest in specific projects or sectors (UNCTAD: 2000, p.12). Several objectives of tax incentives are to improve (a) regional investment, (b) sectoral investment, (c) performance enhancement, and (d) transfer of technology (UNCTAD: 2000, p.12-13). According to Holland and Vann in Thuronyi (1996, p.4-9), tax incentives can be granted to taxpayers in the form of tax holiday, investment allowances, tax credit, timing differences, tax rate reduction, and administrative discretion. In the end, the reduction of tax burden should not decrease state revenues, but it will ultimately have a significant effect on economic productivity and growth (Gandhi, 1995; Rosdiana, 2008). In this case, the concept of tax burden encompasses the cost of taxation incurred.

The term cost of taxation refers to the tax burden of the taxpayers in carrying out their obligations and obtaining their rights. In this case, the costs incurred are not merely material but also immaterial (intangible burden). As quoted from Slemrod and Yitzhaki (Chattopadhyay \& Das-Gupta, 2002; Rosdiana, 2008), there are five indicators of cost of taxation, namely compliance costs, administrative costs, deadweight efficiency loss from taxation, the excess burden of tax evasion and avoidance costs (Rosdiana, 2010). The policies to reduce cost of taxation through regulation and deregulation can be seen as a part of supplyside tax policy. It can be assumed that high cost of taxation will narrow the space for businesses to produce, thereby reducing the supply (Rosdiana, 2008). Compliance costs are defined as a part of administrative burdens incurred by the taxpayers in fulfilling their rights and obligations of taxation, while administrative costs are the costs incurred by the tax authorities to carry out the taxation system (Alink and Kommer: 2011, p.52). Deadweight efficiency loss from taxation, the excess burden of tax evasion and avoidance costs can be categorised as distortion cost incurred as a result of tax collection that requires companies to change 
management strategies, tax management strategies, and behaviors or patterns of habit (Rosdiana and Irianto: 2013, p.175). Compliance costs include tax and other expenses related to the fulfilment of tax obligations. The amount of this tax burden is associated with tax base based on income, consumption, and wealth with different characteristics.

\section{Research Method}

This study applies a qualitative approach, and the analysis is carried out using constructivism paradigm- A qualitative approach is chosen because it can provide a holistic description of a discussed social phenomenon. The data are collected through literature review and field research, including (a) in-depth interviews and (b) Focus Group Discussion (FGD) with the stakeholders. The data collection is carried out along with (1) Philanthropy Learning Forum 2, attended by the philanthropists or philanthropic organizations in Indonesia on December 15, 2015, (2) Parallel Discussion in Indonesia Philanthropy Festival 2016 held at JHCC Jakarta on October 7, 2016 with the theme "Encouraging Fiscal Policy to Support the Role of Philanthropy in Achieving SDGs" and FGD held by the Indonesian Center for Law and Policy Studies (PSHK) collaborating with Knowledge Sector Initiative (KSI) held on May 8, 2017. The data are processed with triangulation process so that the criteria of good worthiness in qualitative study are maintained.

\section{Results}

The Income Tax Law 2008 applicable on January 1, 2009, is a sign of the state's alignment with philanthropy. In the previous regime of Income Tax Law, namely Law No. 17 of 2000 (from now on called Income Tax Law 2000), the Income Tax Law is disincentive to philanthropy since income tax is imposed to philanthropy by shifting the tax burden to the donors (see Figure 1).

Figure 1. The Shifting of Tax Burden of Income Tax to Donors in the Regime of Income Tax Law 2000

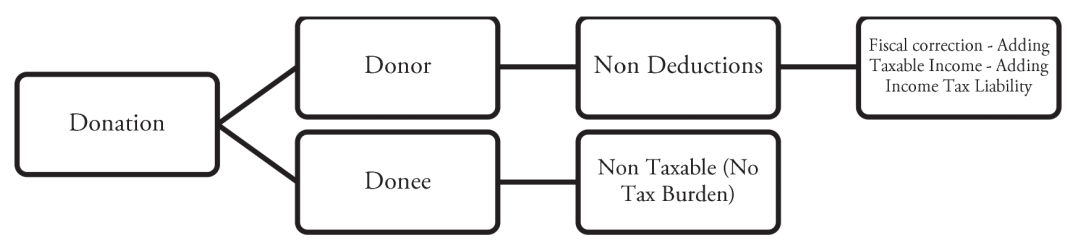

Source: Author's elaboration 
The shifting of tax burden occurs because even though the donation is not an object of income tax for the donee, but the donor cannot make it as a deduction from taxable income. Therefore, positive fiscal correction is necessary to eventually increase taxable income.

In the regime of Income Tax Law 2008, incentives for income tax are granted because there is no tax burden of income tax arising from donations from donor to the donee. However, in practice, these incentives for income tax cannot be utilized in Tax Year 2009 - after the Income Tax Law is implemented - since there is no further government regulation governing this policy. In fact, Article 4 paragraph (3) letter a number 1 of Income Tax Law 2008 states that this provision is regulated by or based on Government Regulation, while the new Government Regulation is enacted by the end of 2010 and applied since Tax Year 2010. More technical provisions, namely the Regulation of the Minister of Finance (the Regulation of the MoF) No. 76 of 2011 is established on April 5, 2011 - after the deadline for filing Annual Personal Income Tax Return and Annual Tax Return of Tax Year 2010 (April 30,2011 ). Thus, many donors who are taxpayers cannot utilize this facility of tax income in Tax Year 2009 and Tax Year 2010. The incentives for income tax cannot be utilized in Tax Year 2009 but can be utilized in Tax Year 2010 if Taxpayers carry out the revision of Tax Return.

Figure 2. Timeline of the Issuance of Tax Policies related to Philanthropy

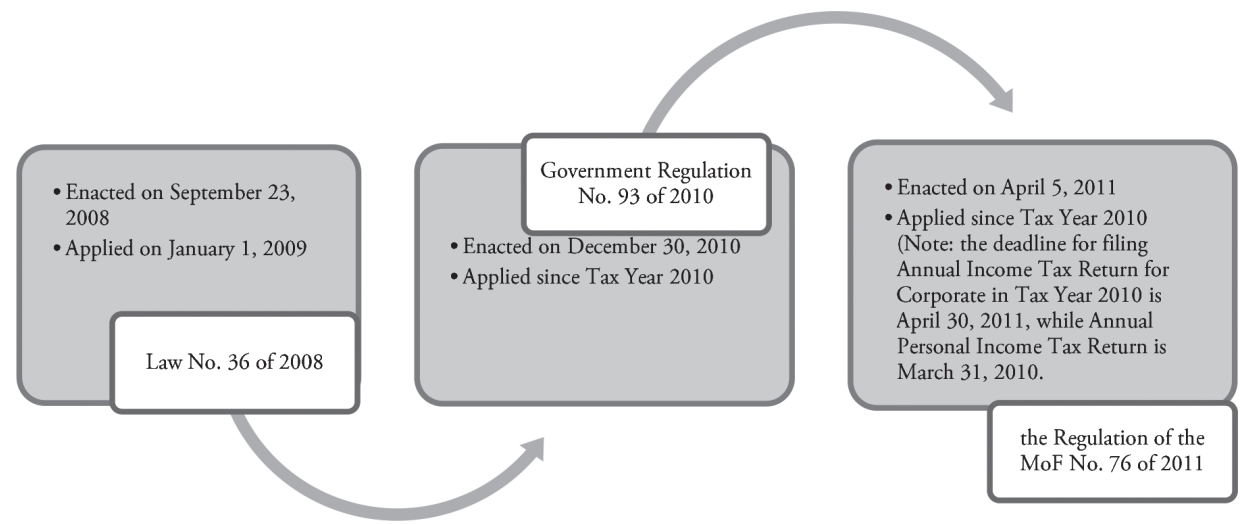

Source: Processed by author

In addition to the issue of legal vacuum causing incentives for income tax cannot be utilized for philanthropy, another important issue is partial tax incentives, for example, unavailability of incentive for VAT and limited tax incentives (see 
Table 1) on donations in the form of goods (including land and buildings). If a donor donates goods, they can be the object of VAT in the form of complementary delivery of Taxable Goods. Other additional taxes will be imposed if there are taxes attached to the delivery of goods by basing on the type or category of the goods, for example, the transfer of land and/or building will be imposed Land and Building Title Transfer Duty (BPHTB) and Income Tax on the Transfer of Rights on Land and/or Buildings. Meanwhile, if the goods are delivered in the form of motor vehicles, in addition to VAT, they will also be imposed Sales Tax on Luxury Goods (if the donor is a producer), Title Transfer Tax for Motor Vehicle and Tax on Motor Vehicle (annually). However, the Law of BPHTB has regulated the exemption from BPHTB for land and/or buildings used for benefaction and religious interests. The scope of the exemption is partial and not on philanthropy in general, but specifically intended for religious activities. However, in practice, many deliveries of goods and/ or services are in the framework of philanthropy but aren't included in the scope of the policy of tax incentives. Overall, the tax incentives granted by the Indonesian government are as follows:

Table 1. Tax Incentives for Philanthropy in Indonesia

\begin{tabular}{|c|c|c|c|}
\hline No. & Regulation & Incentives & Description \\
\hline 1 & $\begin{array}{l}\text { Income Tax Law } 2008 \\
\text { Article } 4 \text { paragraph (3) } \\
\text { letter (a) }\end{array}$ & $\begin{array}{l}\text { Tax exemption } \\
\text { for the excess } \\
\text { profit of } \\
\text { non-profit } \\
\text { organizations }\end{array}$ & $\begin{array}{l}\text { Excluded from the tax object is: } \\
\text { 1. assistance or donations, including zakat } \\
\text { (Islamic alms tax) received by amil zakat } \\
\text { institutions established or approved by the } \\
\text { government and received by the entitled } \\
\text { donee or religious donation required for } \\
\text { the followers of acknowledged religions } \\
\text { in Indonesia, accepted by the religious } \\
\text { institution established or approved by the } \\
\text { government and received by the entitled } \\
\text { donee whose provisions are regulated by } \\
\text { or based on Government Regulation; and } \\
\text { 2. granted assets received by the family } \\
\text { of the direct lineage of one degree, } \\
\text { religious institutions, educational } \\
\text { institutions, social agencies } \\
\text { including foundations, cooperatives, } \\
\text { or individuals running micro and } \\
\text { small enterprises whose provisions are } \\
\text { regulated by or under the Regulation } \\
\text { of the Minister of Finance, as long as } \\
\text { there is no relationship with business, } \\
\text { employment, ownership, or control } \\
\text { among the related parties; }\end{array}$ \\
\hline
\end{tabular}




\begin{tabular}{|c|c|c|c|}
\hline No. & Regulation & Incentives & Description \\
\hline 2. & $\begin{array}{l}\text { 1. Income Tax Law } 2008 \\
\text { Article } 4 \text { paragraph (3) } \\
\text { letter }(\mathrm{m}) \\
\text { 2. The Regulation of } \\
\text { the MoF No. } 80 / \\
\text { PMK.03/2009 on } \\
\text { the Excess Profits } \\
\text { Obtained by Non- } \\
\text { Profit Institutions } \\
\text { Engaged in Education } \\
\text { and/or Research and } \\
\text { Development, Excluded } \\
\text { from Objects of Income } \\
\text { Tax }\end{array}$ & $\begin{array}{l}\text { Tax exemption } \\
\text { for the excess } \\
\text { profit of } \\
\text { non-profit } \\
\text { organizations }\end{array}$ & $\begin{array}{l}\text { 1. Engaged in education and/or research and } \\
\text { development. } \\
\text { 2. Has been registered in the in-charge } \\
\text { institution. } \\
\text { 3. Reinvested in the form of educational } \\
\text { facilities and infrastructure and/or research } \\
\text { and development activities in the longest } \\
\text { period of (four) years since the acquisition of } \\
\text { the excess profits. } \\
\text { 4. Facilities and infrastructure include: } \\
\text { a. Purchase or construction of buildings and } \\
\text { infrastructure of education, research and } \\
\text { development, including the purchase of } \\
\text { land for the construction site. } \\
\text { b. Procurement of facilities and } \\
\text { infrastructure of office, laboratory, and } \\
\text { library. } \\
\text { c. Purchase/construction of student } \\
\text { dormitories, the official residence of } \\
\text { teachers, faculty members or employees, } \\
\text { and sports infrastructure in formal } \\
\text { educational institutions. }\end{array}$ \\
\hline
\end{tabular}

3. 1. Income Tax Law 2008 Article 6 paragraph (1) letter (i), (j), (k), (l), and (m),

2. Government Regulation No. $93 / 2010$ on Donations for National Disaster Relief, Research and Development, Educational Facility, Sports Development, and Social Infrastructure Development Costs Deductible from Gross Income

3. The Regulation of the MoF No.76/PMK.03/ 2011 on Procedures for Reporting and Recording of Donations for National Disaster Relief, Research and Development, Educational Facility, Sports Development, and Social Infrastructure Development Costs Deductible from Gross Income
Tax Deduction for Donations Deductible from Gross Income
Donations for National Disaster Relief, Research and Development in Indonesia, Development of Social Infrastructure, Social Facility, and Sports deductible from gross income. 


\begin{tabular}{|c|c|c|c|}
\hline No. & Regulation & Incentives & Description \\
\hline 4. & $\begin{array}{l}\text { 1. The Regulation of } \\
\text { the MoF No. 609/ } \\
\text { PMK.03/2004 on } \\
\text { Income Tax for Natural } \\
\text { Disaster Donation } \\
\text { in the Provinces } \\
\text { of Nanggroe Aceh } \\
\text { Darussalam (NAD) and } \\
\text { North Sumatra } \\
\text { 2. The Regulation of } \\
\text { the MoF No. 14/ } \\
\text { PMK.03/2005 on } \\
\text { Income Tax Facilities } \\
\text { for Natural Disaster } \\
\text { Donation in the } \\
\text { Provinces of Nanggroe } \\
\text { Aceh Darussalam } \\
\text { (NAD) and North } \\
\text { Sumatra }\end{array}$ & Tax deduction & $\begin{array}{l}\text { Donation in the framework of humanitarian } \\
\text { aid for natural disaster in NAD and North } \\
\text { Sumatra in } 2004 \text { can be expensed. }\end{array}$ \\
\hline
\end{tabular}

5. VAT of Complementary

Provision of Taxable Goods

(BKP) and/or Taxable

Services (JKP)

1. Article 1A paragraph (1)

letter (d) of Law No. 42

of 2009 on VAT

2. Article 5 of Government

Regulation No.

1 of 2012 on the implementation of the

Law on VAT

3. The Regulation of the MoF No. $75 /$

PMK.03/2010 on Other

Values as Tax Basis

4. The Regulation of

Directorate Generale

of Taxation No.

PER-22/PJ/2012

on the revocation

of KEP-87/PJ/2002

on the imposition of

VAT and Sales Tax

on Luxury Goods on

Self-Utilization and/

or Complementary

Provision of Taxable

Goods and/or Taxable

Services
Unavailable

Article 1A paragraph (1) letter (d) of Law

No. 42 of 2009:

The definition of the delivery of

Taxable Goods is self-utilisation and/or

complementary provision of Taxable Goods

\section{Description:}

Self-utilization means the use for the benefit of self-employers, administrators, or employees, either self-produced goods or not. Complimentary provision is the provision given without payment for either self-produced goods or not, such as the provision of samples of goods for sale to the buyer.

\section{Article 4 paragraph (1) letter (c) of Law No. 42 of 2009:}

The delivery of taxable services must meet the following conditions:

a. the services are Taxable Services,

b. the delivery is carried out within the Customs Area; and

c. the delivery is carried out in business activity or work.

The definition of the delivery of Tax Services is self-utilization and/or complementary provision of Taxable Services 


\begin{tabular}{ccll}
\hline No. & \multicolumn{1}{c}{ Regulation } & \multicolumn{1}{c}{ Incentives } & \multicolumn{1}{c}{ Description } \\
\hline 6. & $\begin{array}{l}\text { 1. Article } 85 \text { paragraph (4) } \\
\text { of Law No. 28 of 2009 } \\
\text { on Regional Tax and }\end{array}$ & $\begin{array}{l}\text { Tax exemption } \\
\text { with limited } \\
\text { scope }\end{array}$ & $\begin{array}{l}\text { Objects that are not subject to BPHTB are } \\
\text { the objects obtained by: }\end{array}$ \\
$\begin{array}{ll}\text { 2. Article } 3 \text { of Law No. 20 } \\
\text { of 2000 on BPHTB }\end{array}$ & & $\begin{array}{l}\text { 1. individuals or corporates because of } \\
\text { benefactions; and }\end{array}$ \\
& & $\begin{array}{l}\text { 2. individuals or corporates used for } \\
\text { religious interests }\end{array}$ \\
\hline
\end{tabular}

Source: Processed by author

\section{Discussion}

One of the types of tax incentives for philanthropy is tax exemption and deduction on Income Tax of individuals and corporates. Tax incentives provided tend to be limited to the application of the concept of tax exemption and tax deduction. The regulations concerning tax incentives are deemed inadequate to provide clear guidance, particularly related to the lack of scope of the incentives and the tax administration. In the context of incentives for income tax, the tax deduction is generally granted to specific sectors limited to the sectors of education, development, and research as regulated in Income Tax Law 2008.

The establishment of Income Tax Law 2008 is considered as the momentum for the government to consider economic and social forces of philanthropy, where the definition of donations as the objects of tax incentives is not limited to merely religious donations, but also other donations in the aforementioned sectors. Unfortunately, other sectors such as sports, arts and culture have not been considered in the formulation of the law. Furthermore, the creative, arts and cultural industries are not included in the sectors granted the incentives for income tax. According to international best practice, several countries such as Ireland, the Netherlands, Germany and the United States grant tax incentives for artists, arts and cultural activities as well as the location of the art industry (Utilizing, n.d.). Two years later, Government Regulation No. 93 of 2010 is established eventually and includes arts and cultural activities as the object of incentives for income tax.

Government Regulation No. 93 of 2010 describes the scope of other sectors entitled to obtain the incentives for income tax. The Government Regulation includes two additional sectors, namely sports development and social infrastructure (Tax, 2008). Social infrastructure includes facilities and infrastructure supporting the development of arts and cultural activities. However, the addition is still deemed too inflexible and limited, considering that many other sectors may be crucial to obtain funding and tax incentives such as the health sector that requires funding for 
medical research and development of certain diseases (namely AIDS and bird flu), activities related to gender issues, environmental changes, and many others.

Even though the arts and cultural activities become the objects of incentives for income tax, the government's commitment in formulating the policy of tax incentives in Income Tax Law 2008 is frequently less on target and untimely. In this case, the government misses the crucial sectors to be the objects of incentives for income tax. Therefore, the wider scope is later regulated in the Government Regulation. The issue of time is visible in the formulation process of incentives for income tax regulated in Income Tax Law 2008 applied on January 1, 2009. The socialization of this policy is not optimal, and the derivative regulation further regulating the incentives for income tax is published in 2010 as stipulated in Government Regulation No 93 of 2010.

Moreover, the next derivative regulation, namely the Regulation of the MoF No. 76 of 2011, is established on April 5, 2011 - after the deadline for filing Annual Personal Income Tax Return and Annual Tax Return of Tax Year 2010 (April 30, 2011). Such conditions give disadvantage to the taxpayers or philanthropy activists in terms of time cost, where there are two missing Tax Years (2009 and 2010) that should be utilized by the taxpayers to get tax incentives. The incentives for income tax cannot be utilized in Tax Year 2009 but can be utilized in Tax Year 2010 if Taxpayers carry out the revision of Tax Return.

In the policy of tax incentive for philanthropy, the Government tends to regulate the types of religious donations that are compulsory and submitted to the institution or the party licensed or authorized or established by the government. Although the policy considers the aspects of administration in terms of the donations should be distributed to institutions with clear legality, the definition of 'compulsory' in practice may cause dispute and uncertainty of definition. The indicator of 'compulsory' donations or activities in any religious context acknowledged by the government needs to be further explored. For example, Islam has a category of compulsory donations, (namely zakat al-mal or Islamic alms based on wealth, profession, and property) and optional donations (namely infaq or sadaqa-Islamic almsgiving — and other optional alms). It is regulated in the tax policies, such as the indicator of 'zakat' is excluded from the object of income tax. Thus, infaq and alms in Islam are included as the objects of income tax since it constitutes optional donations that are mentioned in the Law. However, the government needs to clarify the compulsory donations in the clause "compulsory religious donations for the followers of acknowledged religions in Indonesia", considering Indonesia acknowledges six religions (namely Islam, Protestantism, Catholicism, Hinduism, 
Buddhism and Confucianism) and each religion has respective provisions related to compulsory donations.

Regarding philanthropy with CSR obligations for companies operating in Indonesia, there is a frequent overlap of interest in CSR policy implemented by the companies. The obligation for CSR activities is frequently diverted on CSR activities that benefit the companies. The Law on CSR issued in 2007 mandates the companies in the sectors of natural resources to allocate $2 \%$ of their budget to charity or CSR activities. In fact, it is difficult to implement, and most large companies choose to implement their activities by themselves rather than looking for partners of non-profit organizations with expertise in particular fields (Davis, 2011, p.17). Generally, companies tend to distribute funds for CSR activities through self-managed foundations (Rosser and Edwin 2010; Anand in 2014 in Davis, 2011, p.14).

In some cases, companies choose to distribute funds through their own foundations, for example Sampoerna Foundation, Rajawali Foundation, Lippo Group, or Bosowa Group acting as intermediaries to distribute funds from the main company. The foundations also implement social programs directly. Thus, it is difficult to determine whether the funds from private sectors are effective source of funds for philanthropy considering the essence and objectives of the activities cannot be given to public interest, but rather for the benefit of the companies. Such condition is loopholes in tax regulations governing philanthropy. The government needs to consider the type of control mechanism required so that the CSR obligations of the companies can be effectively distributed to the public.

A similar thing occurs in the policy of tax incentives for philanthropy. CSR companies generally allocate their profits for donations to the activities of development and construction of educational, sports and research facilities generally managed by their foundations. If the foundations are included in the category of entitled institutions to receive incentives for tax deduction or tax exemption on their income, it obviously becomes the loopholes for implementers of CSR to obtain tax incentives for their own companies. In this case, the clause of who can utilize tax incentives needs to be clarified to reduce such loopholes.

Regardless of loopholes in the utilization of tax incentives by CSR, the study carried out by Vidia (2014) shows that most companies are not aware of any tax incentives on the establishment of certain CSR, even the CSR activities of companies are not based on the existence of tax incentives for CSR expenditure. It indicates that CSR implementers tend to not aware of any tax incentives provided by the government and that the socialization of the government related to tax incentives is 
low. The government is responsible for creating a regulatory environment that may influence the activities of transfer of public and company funds, including CSR funds of private sectors and tax-exempts status for private donations. The study also indicates a lack of socialization on tax incentives for philanthropy by the government. On the other hand, the Law on CSR also has not regulated clearly about what CSR activities are and what the companies should do regarding CSR activities in accordance with applicable laws. The combination of Law on CSR and the lack of incentives to encourage the distribution of funds from private parties prevents the growth of a more institutionalized philanthropic community (Davis, 2011, p.14).

Basically, the government should provide impartial tax incentives or subsidies for philanthropy. Observed from the perspective of supply-side tax policy, if the government provides incentives for philanthropy in the hope that the activities of management of philanthropy can prosper the community, the government can reduce the subsidies for social activities (see Figure 3).

Figure 3. Supply-Side Tax Perspective related to the Policy of Tax Incentive for Philanthropy

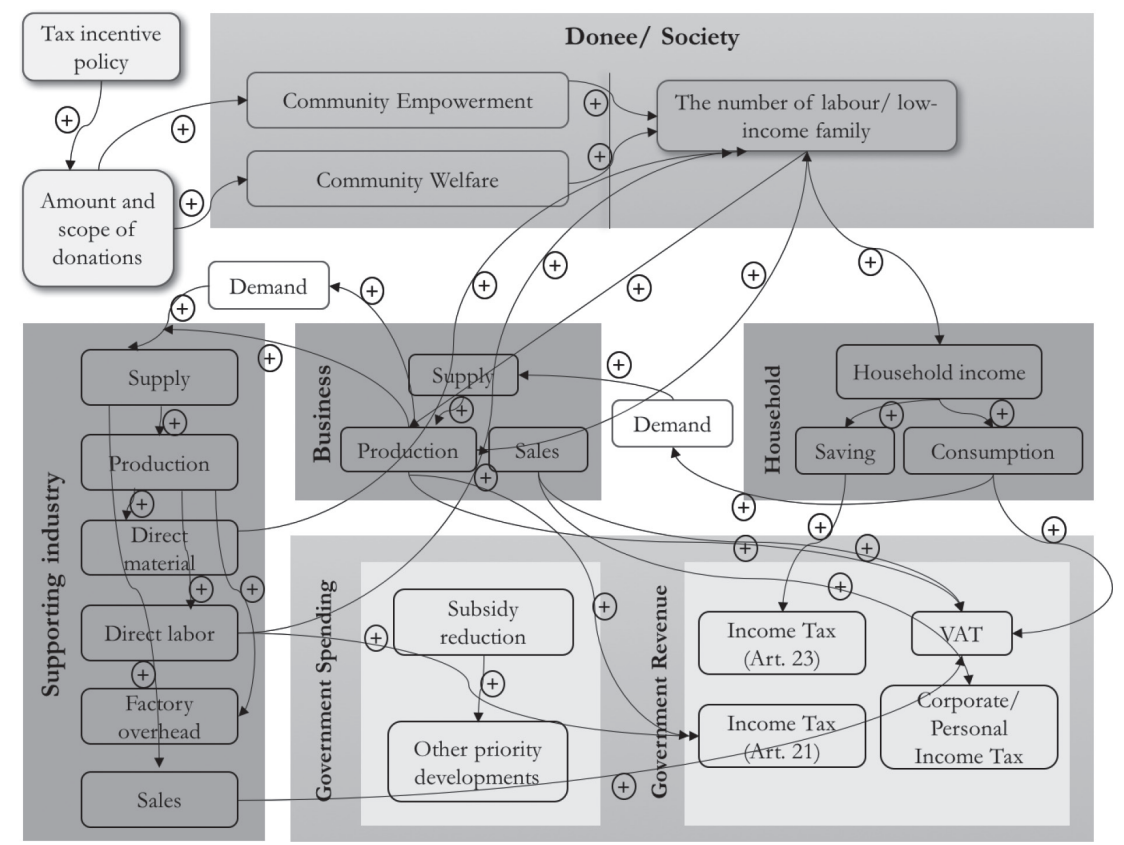

Source: Processed by author 
As seen in Figure 2, it is, in fact, similar to the fact that the government provides subsidies (from tax revenue) by providing deduction managed by nonprofit organizations from donors to fund activities prospering the community. If it is eventually able to prosper the community, reduce poverty, and empower the community, the government will get revenue from other types of taxes. More prosperous community and less poor community will increase the purchasing power of the community. The increase in purchasing power will encourage the increase of supply. Thus, theoretically, it does not merely increase the revenue of VAT, but also the revenue of income tax article 21, article 23 and other taxes related to business activities.

\section{Conclusion}

The policy of tax incentives for philanthropy has been an international best practice in line with the change of paradigm of the government, leading to the strengthening of public participation. Tax incentives for philanthropy in Indonesia are limited so that more comprehensive and holistic improvement of tax policy by expanding the types of incentives for other types of taxes is necessary, for example, by not only providing incentives for income tax but also extending the scope of tax incentives for consumption and property such as BPHTB and VAT (transfer of rights of goods). Crucial sectors such as health sector outside the specified sectors in the policy of tax incentives also need to be studied to be the objects of tax incentives since basically philanthropy is not limited to a particular sector as long as it is related to the efforts to utilize the funds for social activities. Therefore, the policy of tax incentive supporting the role of philanthropy in achieving the development goals or other government programs (namely sustainable development goals) is necessary.

Currently, the tax policy is still limited as a pull factor of acceleration of philanthropy in line with the efforts to achieve development goals (including Sustainable Development Goals). In this case, the re-construction of tax policies to encourage philanthropy to support the achievement of government programs is necessary. The policy of tax incentives for philanthropy to encourage the achievement of government programs should be carried out comprehensively, holistically, and impartially so that there will be a balance between pull and push factor.

\section{References}

Alink, Matthijs \& Victor van Kommer. 2001. Handbook on tax administration. Amsterdam: IBFD. 
Charities Aid Foundation (CAF). 2017. CAF World Giving Index 2017: A global view of giving trends.

Chattopadhyay Saumen \& Arindam Das-Gupta. 2002. "The Compliance Cost of the Personal Income Tax and its Determinants." National Institute of Public Finance and Policy New Delhi: 1-199.

Creswell, Jhon, W., 1998. Qualitative Inquiry and Research Design: Choosing Among Five Designs. Thousand Oaks, CA: Sage.

Davis, Ben. 2011. "Financial Sustainability and Diversification of Financing: Challenges for Indonesian NGOs." Department of Foreign Affairs and Trade: 1-23.

Gandhi, Ved P. 1995. Supply-Side Tax Policy; Its Relevance to Developing Countries. Washington, DC: International Monetary Fund.

Garciaa, Silvia, Una Osili \& Xiaonan Kou. 2017. "Measuring Philanthropic Freedom Across Countries." Paper presented at European Research Network on Philanthropy 8th International Conference, Copenhagen: 1-16.

Hudson Institute. 2016. The Index of Global Philanthropy and Remittances 2016. Washington, DC: Hudson Institute.

Koele, Ineke, A., 2007. International taxation of philanthropy, 2007. Amsterdam: IBFD

Kweifio-Okai, Carla. 2014. Where did the Indian Ocean tsunami aid money go? Retrieved from https:/www.theguardian.com/global-development/2014/ dec/25/where-did-indian-ocean-tsunami-aid-money-go

. 2016. Philanthropy is the Pillar of Development, October 2016. Retrieved from https://www.kompas.com

Rosdiana, Haula. 2008. "Reconstruction of the Concept of Supply-side Tax Policy." Bisnis dan Birokrasi, 15(3): 202-205.

Rosdiana, Haula. 2010. "Reformulating Policy on Frequency Usage Fees as NonTax State Revenue: Urgency and Its Implications." Journal of Indonesian Economy and Business, 25: 222-238.

Rosdiana, Haula \& Edi Slamet Irianto. 2013. Introduction of Taxation: Policy and Implementation in Indonesia. Jakarta: Rajawali Pers.

. 2008. Tax Incentives for Art-Culture-September 28. Retrieved from https:// koran.tempo.

Thuronyi, Victor. 1996. Tax law design and drafting. International Monetary Fund.

United Nations Conference on Trade and Development (UNCTAD). 2000. Tax incentives and foreign direct investment: A Global Survey. New York: United Nations Publications. 
2017. Utilizing Tax Incentives to Cultivate Cultural Industries and Spur ArtsRelated Development. Retrieved from https://www.mtauburnassociates.com/ pubs/Utilizing_Tax_Incentives_to_Cultivate_Cultural_Industries.pdf

Wiepking, Pamala \& Femida Handy. 2015. The Palgrave Handbook of Global Philanthropy. United Kingdom: Palgrave Macmillan

Law on Corporate Social Responsibility. 2013. Retrieved September 21, 2017. from http://www.hukumonline.com/klinik/detail/lt52716870e6a0f/aturanaturan-hukum-corporate-social-responsibility

Law No. 20 of 2000. Duty on the Acquisition of Rights to Land and Building. Jakarta: JDIH BPK RI.

Law No. 36 of 2008. Income Tax. Jakarta: Direktorat Jendral Pajak.

Law No. 28 of 2009. Regional Tax and Regional Retribution. Jakarta: JDIH BPK RI. Law No. 42 of 2009. Value Added Tax. Jakarta: JDIH BPK RI.

Government Regulation No. 93/2010. Donations for National Disaster Relief, Research and Development, Educational Facility, Sports Development, and Social Infrastructure Development Costs Deductible from Gross Income

The Regulation of Directorate General of Taxation No. PER-22/PJ/2012. The revocation of KEP-87/PJ/2002 on The Imposition of VAT and Sales Tax on Luxury Goods on Self-Utilization and/or Complementary Provision of Taxable Goods and/or Taxable Services.

The Regulation of the Ministry of Finance No. 14/PMK.03/2005. Income Tax Facilities for Natural Disaster Donation in the Provinces of Nanggroe Aceh Darussalam (NAD) and North Sumatra.

The Regulation of the Ministry of Finance No. 75/PMK.03/2010. Other Values as Tax Basis.

The Regulation of the Ministry of Finance No. 80/PMK.03/2009. The Excess Profits Obtained by Non-Profit Institutions Engaged in Education and/or Research and Development, Excluded from Objects of Income Tax.

The Regulation of the Ministry of Finance No.76/PMK.03/ 2011. Procedures for Reporting and Recording of Donations for National Disaster Relief, Research and Development, Educational Facility, Sports Development, and Social Infrastructure Development Costs Deductible from Gross Income.

The Regulation of the Ministry of Finance No. 609/PMK.03/2004. Income Tax for Natural Disaster Donation in the Provinces of Nanggroe Aceh Darussalam (NAD) and North Sumatra. 